\title{
Nano-Zn Increased Zn Accumulation and Triglyceride Content by Up-Regulating Lipogenesis in Freshwater Teleost, Yellow Catfish Pelteobagrus fulvidraco
}

\author{
Shi-Cheng Ling ${ }^{1}$, Mei-Qin Zhuo ${ }^{1}$, Dian-Guang Zhang ${ }^{1}$, Heng-Yang Cui ${ }^{1}$ and Zhi Luo ${ }^{1,2, *(0)}$ \\ 1 Key Laboratory of Freshwater Animal Breeding, Ministry of Agriculture, Fishery College, Huazhong \\ Agricultural University, Wuhan 430070, China; 15907174014@webmail.hzau.edu.cn (S.-C.L.); \\ zmq@mail.hzau.edu.cn (M.-Q.Z.); ZDG@webmail.hzau.edu.cn (D.-G.Z.); \\ cuihengyang@webmail.hzau.edu.cn (H.-Y.C.) \\ 2 Laboratory for Marine Fisheries Science and Food Production Processes, Qingdao National Laboratory for \\ Marine Science and Technology, Qingdao 266237, China \\ * Correspondence: luozhi99@mail.hzau.edu.cn; Tel.: +86-27-8728-2113; Fax: +86-27-8728-2114
}

Received: 15 December 2019; Accepted: 24 February 2020; Published: 27 February 2020

\begin{abstract}
The present study was conducted to explore the mechanism of nano-Zn absorption and its influence on lipid metabolism in the intestine of yellow catfish Pelteobagrus fulvidraco. Compared to $\mathrm{ZnSO}_{4}$, dietary nano- $\mathrm{Zn}$ addition increased the triglyceride (TG) content, enzymatic activities of malic enzyme (ME) and fatty acid synthase (FAS), and up-regulated mRNA levels of $6 \mathrm{pgd}$, fas, acca, dgat1, ppar $\gamma$, and fatp4. Using primary intestinal epithelial cells of yellow catfish, compared to the $\mathrm{ZnSO}_{4}$ group, nano- $\mathrm{Zn}$ incubation increased the contents of TG and free fatty acids (FFA), the activities of glucose-6-phosphate dehydrogenase (G6PD), 6-phosphogluconate dehydrogenase (6GPD), ME, and FAS, up-regulated mRNA levels of lipogenic genes (6pgd, g6pd, fas, dgat1, and ppar $\gamma$ ), genes of lipid transport (fatp4 and ifabp), and Zn transport genes (znt5, znt7, $m t$, and $m t f 1)$, and increased the protein expression of fatty acid transport protein 4 (FATP4) and peroxisome proliferator activated receptor gamma (PPAR $\gamma)$. Further studies found that nano-Zn absorption was via the clathrin-dependent endocytic mechanism. PPAR $\gamma$ mediated the nano-Zn-induced increase in TG, and nano- $\mathrm{Zn}$ increased $\mathrm{Zn}$ accumulation and induced TG accumulation by activating the PPAR $\gamma$ pathway and up-regulating lipogenesis.
\end{abstract}

Keywords: nano-Zn; clathrin pathway; PPAR $\gamma$; lipid metabolism; vertebrates

\section{Introduction}

Zinc $(\mathrm{Zn})$ is an essential nutrient required in animals for many important biological processes, including growth, development, and nutrient metabolism [1]. Dietary Zn deficiency or excess adversely affects biochemical processes and growth in fish. In vertebrate animals, the absorption of Zn mainly occurs in the intestinal tract [2]. Adequate $\mathrm{Zn}$ absorption from the intestine is essential for the body, but a high level of $\mathrm{Zn}$ absorption will be harmful [2]. Therefore, maintaining an appropriate $\mathrm{Zn}$ level is critically important. Zn uptake and the regulation of homeostasis are achieved through many key proteins and genes [3]. These proteins consist of metal-response transcription factor-1 (MTF-1), metallothionein (MT), and transmembrane transporters (ZIP and ZnT families) [4]. MTF-1 is the only $Z n$-sensing transcription factor in vertebrates and regulates the transcription of many genes involved in Zn metabolism [3]. MT is important for cytosolic Zn storage. ZIP transporters, such as ZIP4, play prominent roles in the $\mathrm{Zn}$ uptake and transport of $\mathrm{Zn}$ from outside the cell into the cytoplasm [3]. ZnT transporters, such as ZnT1, ZnT5, and ZnT7, mobilize Zn from the cytosol into the extracellular space and the lumens of intracellular compartments $[3,5,6]$. The regulation of dietary $\mathrm{Zn}$ absorption in 
the intestine is believed to be important in $\mathrm{Zn}$ homeostasis and has been studied in rodent models, but not in fish. The molecular mechanism for $\mathrm{Zn}$ uptake and homeostatic regulation remains unknown in fish.

As $\mathrm{Zn}$ is an essential microelement in fish, many studies have been performed to determine the effects of dietary $\mathrm{Zn}$ levels on growth performance, body composition, and nutrient metabolism $[7,8]$. In our laboratory, studies have suggested that dietary $\mathrm{Zn}$ addition significantly influence lipid deposition and metabolism by regulating enzymatic activities and genes expression, including lipogenic enzymes and genes: Glucose-6-phosphate dehydrogenase (G6PD), 6-phosphogluconate dehydrogenase (6GPD), acetyl-CoA carboxylase (ACC), fatty acid synthase (FAS), and transcription factors peroxisome proliferator-activated receptor gamma (PPAR $\gamma$ ) and sterol regulatory element binding protein-1 (SREBP-1), which, in turn, affects health and fillet quality [9]. In these studies, inorganic $\mathrm{Zn}$ has been used as an additive in the diets. However, low utilization efficiency is the biggest issue for its application because low $\mathrm{Zn}$ utilization in fish leads to excess $\mathrm{Zn}$ excretion in the aquatic environment and causes environmental pollution. Meanwhile, studies have suggested that its effects of dietary $\mathrm{Zn}$ levels depend on the chemical forms of $\mathrm{Zn}$ because its chemical form affects Zn absorption and utilization [10,11]. Zn nanoparticles (nano-Zn), as a substitute to the conventional $\mathrm{Zn}$ sources, can be a good alternative in aquatic feed. It has been reported that nanoparticles showed new characteristics of transport and uptake and exhibited a higher absorption efficiency $[10,11]$. Thus, nano-Zn may be used in feed to provide better results than inorganic $\mathrm{Zn}$ sources and indirectly prevent environmental contamination. Zn nanoparticles have been reported to enhance growth performance and improve feed utilization and many other beneficial effects in fish [12,13]. However, the cellular mechanisms of these particles are not well understood. In mammals, it has been reported that $\mathrm{Zn}$ nanoparticles are internalized in cells via the endocytic pathway. Endocytosis is a conserved process in eukaryotes by which extracellular components are taken up into cells by invagination of the plasma membrane to form vesicles that enclose these materials [14]. There are four main endocytic pathways for internalizing nanoparticles, such as macropinocytosis, clathrin-dependent, caveolae-dependent, and clathrin-caveolae-independent endocytosis $[14,15]$. Understanding which of these pathways are involved in nano-Zn uptake is critical to clarifying the regulatory mechanism of nano- $\mathrm{Zn}$ in fish.

As a continuation of our series of studies involved in $\mathrm{Zn}$ nutrition and its relationship with lipid metabolism in fish, the present study was conducted to compare the effects and mechanism of dietary $\mathrm{ZnSO}_{4}$ and nano- $\mathrm{Zn}$ addition influencing $\mathrm{Zn}$ absorption and lipid metabolism in the intestinal tract of yellow catfish Pelteobagrus fulvidraco, an omnivorous freshwater fish widely distributed in China and other Asian countries. Considering that two $\mathrm{Zn}$ sources (inorganic and nano-Zn) exist in aquatic environments and aquatic feedstuffs, our study provided important references and mechanistic insights for the evaluation and assessment of $\mathrm{Zn}$ nutrition and hazards in vertebrates.

\section{Results}

\subsection{Growth Performance, Feed Utilization, and Morphological Parameters}

Survival, feed intake (FI), and intestinal somatic index (ISI) showed no significant differences between the two groups (Supplementary Table S2). Weight gain (WG), specific growth rate (SGR), viscerosomatic index (VSI), and condition factor (CF) were higher in thenano-Zn groups than in the $\mathrm{ZnSO}_{4}$ group. By contrast, feed conversion rate (FCR) was higher in the $\mathrm{ZnSO}_{4}$ group than in the nano-Zn group (Supplementary Table S2).

\subsection{Zn Accumulation, $\mathrm{Zn}$ Absorption, and Lipid Metabolism in the Intestine}

Intestinal $\mathrm{Zn}$ content and $m t f-1 \mathrm{mRNA}$ expression were higher in the nano-Zn group than in the $\mathrm{ZnSO}_{4}$ group (Figure 1A,B). mRNA levels of $z i p 4, z n t 1, z n t 5, z n t 7$, and $m t$ showed no significant differences between the two groups. Compared to $\mathrm{ZnSO}_{4}$, nano- $\mathrm{Zn}$ increased the triglyceride (TG) content, enzymatic activities of malic enzyme (ME) and FAS, and up-regulated mRNA levels of $6 \mathrm{pgd}$, 
fas, acca, dgat1, ppary, and fatp4 (Figure 1C-E). mRNA levels of $g 6 p d$, srebp-1, and $i$-fabp showed no significant differences between the other two groups.
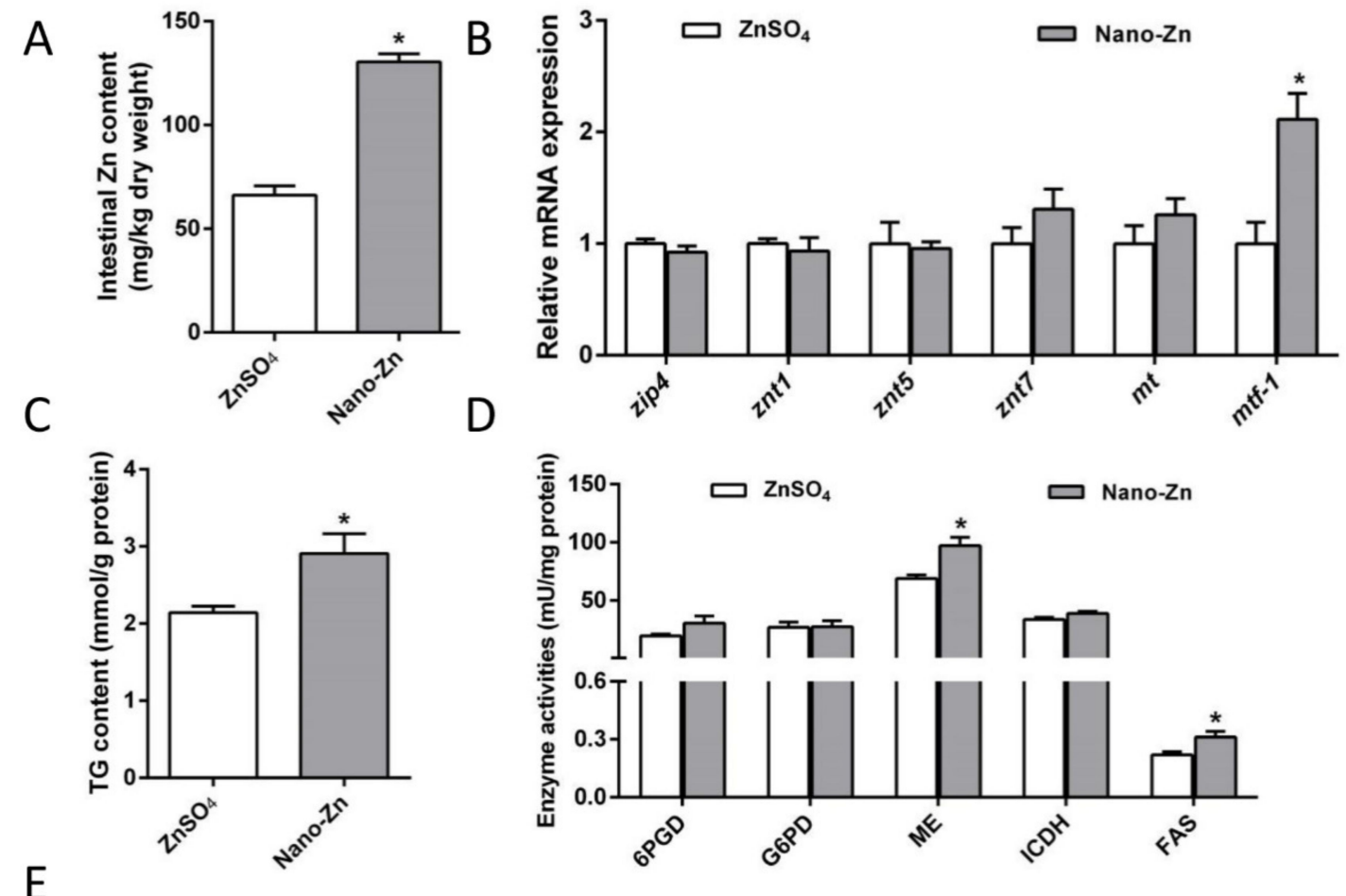

$\mathrm{E}$

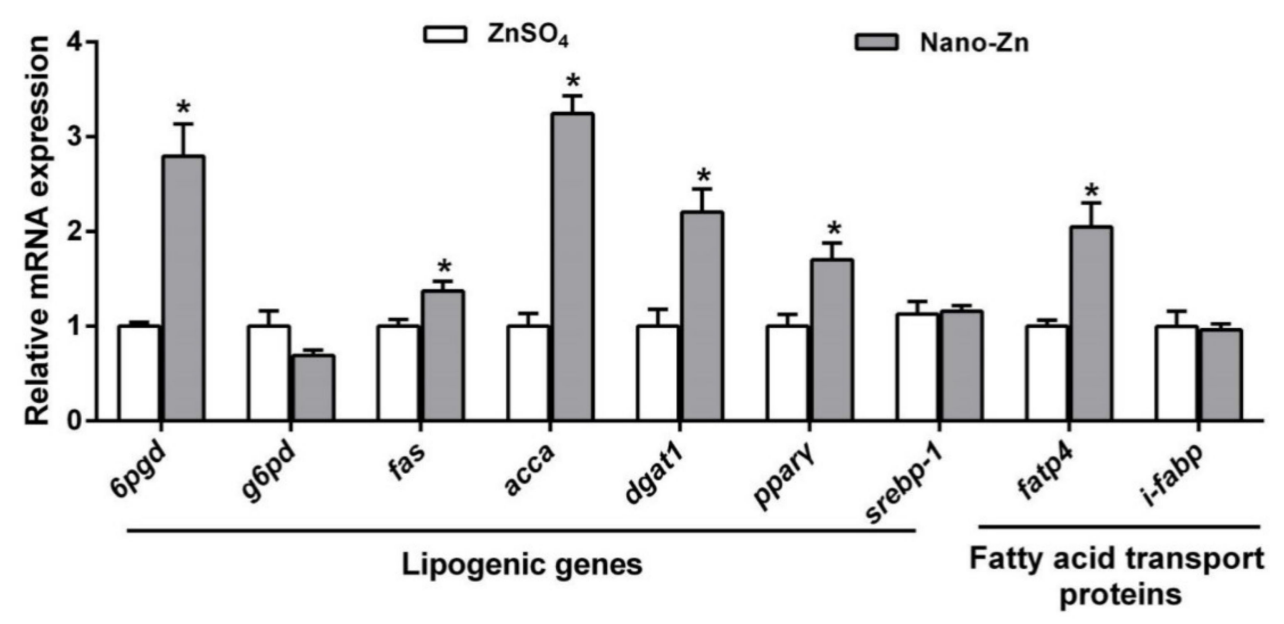

Figure 1. Effects of two $\mathrm{Zn}$ sources on $\mathrm{Zn}$ transport proteins and lipid metabolism of the intestine of yellow catfish. (A) Zn content. (B) The mRNA levels of Zn transport protein. (C) Triglyceride (TG) content. (D) Enzyme activities. (E) The mRNA levels of the lipogenic genes. Values indicate means \pm SEMs, $n=3$. The mRNA levels of genes from the $\mathrm{ZnSO}_{4}$ group were considered to be 1 . Asterisks (*) indicate significant differences between $\mathrm{ZnSO}_{4}$ and the nano- $\mathrm{Zn}$ group $(p<0.05)$.

\subsection{Intestinal Epithelial Cells Absorb Nano-Zn via Clathrin Pathway}

To explore the mechanism of nano-Zn absorption by intestinal epithelial cells, the primary intestinal epithelial cells from yellow catfish were isolated and several in vitro experiments were conducted. The 3-(4,5-dimethylthiazol-2-yl)-2,5-diphenyltetrazolium bromide (MTT) assay showed that nano-Zn concentrations of lower than $40 \mu \mathrm{M}$ had no adverse influence on cell viability (Figure 2A). Green fluorescence intensity by a $\mathrm{Zn}^{2+}$ fluorescent probe increased with nano- $\mathrm{Zn}$ incubation in a 
concentration- and time-dependent manner (Figure 2B-E). TG content increased with increasing nano-Zn concentration (Figure 2F).
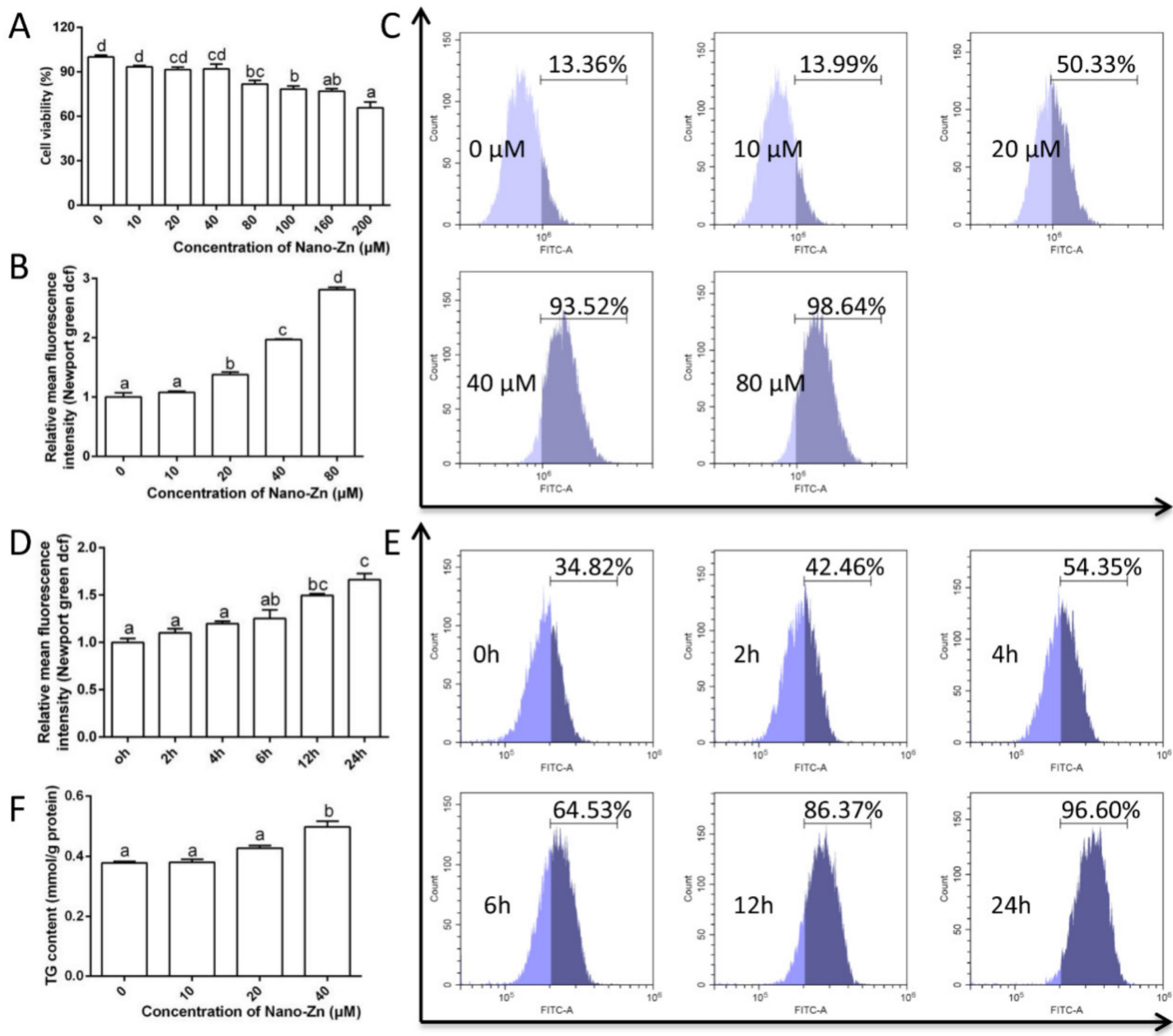

Figure 2. Nano- $\mathrm{Zn}$ enhanced the content of free $\mathrm{Zn}^{2+}$ and TG accumulation in the intestinal epithelial cells of yellow catfish. (A) Cell viability after $24 \mathrm{~h}$ of nano-Zn incubation. (B) The free $\mathrm{Zn}^{2+}$ quantified by calculating FL1 (green) mean fluorescence intensity (Newport Green DCF) after the primary intestinal epithelial cells were incubated with nano-Zn for $24 \mathrm{~h}$. (C) The presence of Newport Green DCF-stained $\mathrm{Zn}^{2+}$ demonstrated by flow cytometry analysis of green (FL1) fluorescence intensity after the primary intestinal epithelial cells were incubated with nano-Zn for $24 \mathrm{~h}$. (D) The free $\mathrm{Zn}^{2+}$ was quantified by calculating the FL1 (green) mean fluorescence intensity (Newport Green DCF) after the primary intestinal epithelial cells were incubated with $40 \mu \mathrm{M}$ nano-Zn. (E) The presence of Newport Green DCF-stained $\mathrm{Zn}^{2+}$ was demonstrated by flow cytometry analysis of green (FL1) fluorescence intensity after the primary intestinal epithelial cells were treated with $40 \mu \mathrm{M}$ nano-Zn. (F) TG content after $24 \mathrm{~h}$ of nano-Zn incubation. Values indicate means $\pm \mathrm{SEMs}, n=3-6$. Different letters indicate significant differences among groups at $p<0.05$.

Compared to the $\mathrm{ZnSO}_{4}$ group, nano- $\mathrm{Zn}$ incubation increased the protein level of MTF1 (Supplementary Figure S1A) and mRNA levels of Zn transport genes (znt5, znt7, $m t$, and $m t f 1$ ), but not the mRNA levels of zip4 and znt1 (Supplementary Figure S1B).

To investigate the role of specific endocytic pathways in the internalization of nano-Zn, primary intestinal epithelial cells were treated with a range of inhibitors: $\mathrm{NaN}_{3}$, chlorpromazine (CHL), nystatin, and cytochalasin $\mathrm{D}$ (Cyto D). Here, $\mathrm{NaN}_{3}$ pretreatment significantly alleviated the $\mathrm{Zn}$ uptake of the nano-Zn source, but nystatin showed no significant effects on $\mathrm{Zn}$ absorption of the nano-Zn source (Supplementary Figure S2A-C). CHL pretreatment, but not cytochalasin D, significantly alleviated 
the $\mathrm{Zn}$-induced increase in nano-Zn absorption (Figure 3A-C), indicating that the absorption of the nano-Zn source was via the clathrin pathway.

A

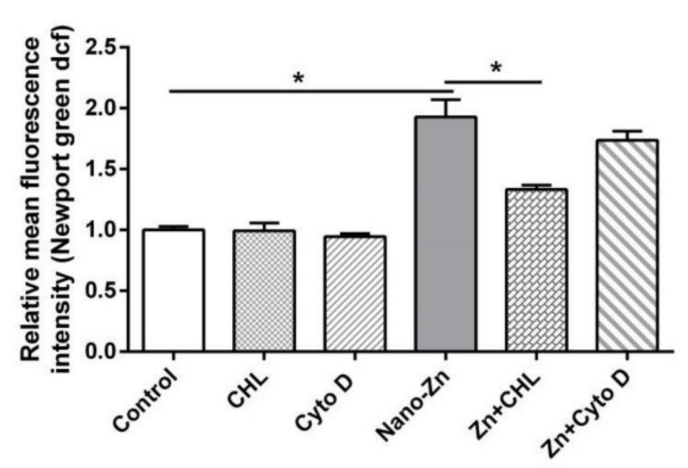

B
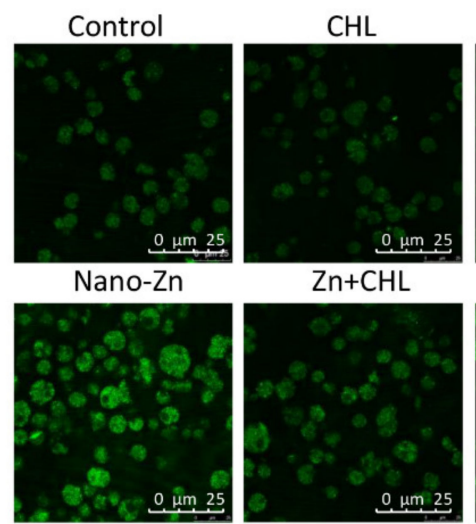

$\mathrm{Zn+CHL}$
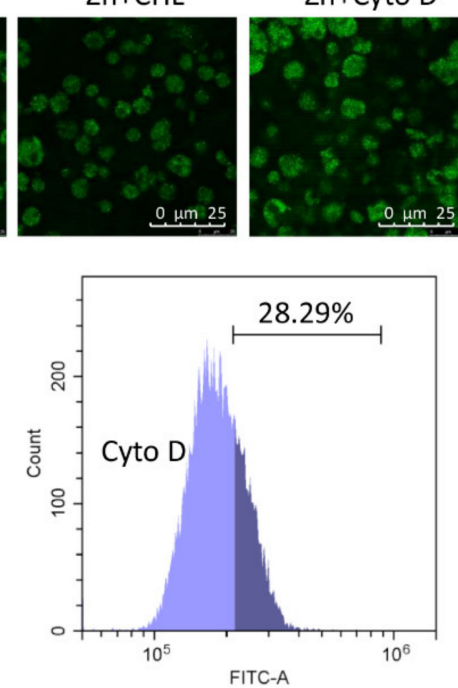

FITC-A

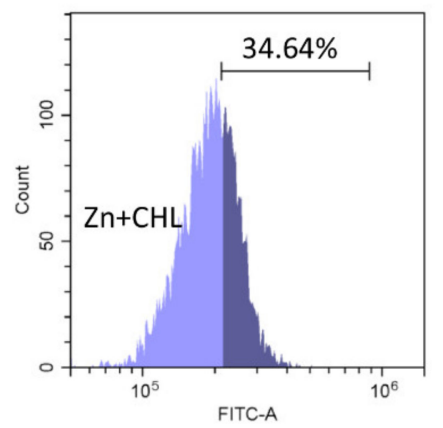

Cyto D

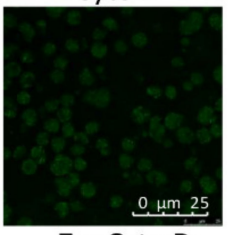

Zn+Cyto D

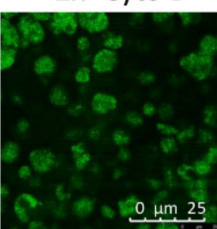

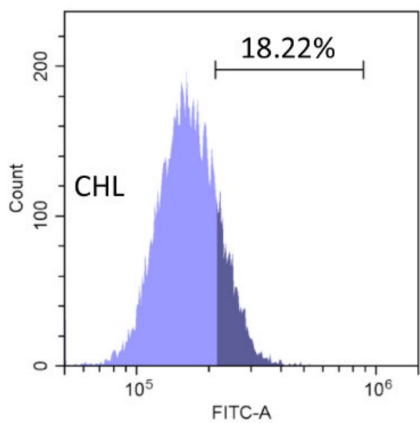

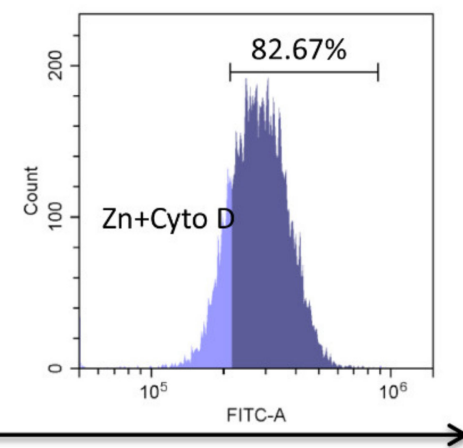

C
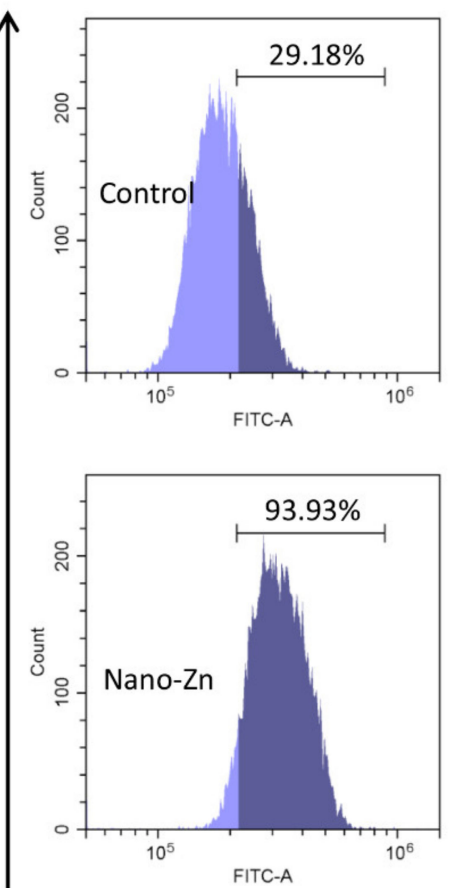

Figure 3. Effect of nano-Zn on clathrin pathway in intestinal epithelial cells. (A) Free $\mathrm{Zn}^{2+}$ was quantified by calculating the FL1 (green) mean fluorescence intensity of intestinal epithelial cells incubated for $12 \mathrm{~h}$ in $40 \mu \mathrm{M}$ nano-Zn with $2 \mathrm{~h}$ of $10 \mu \mathrm{g} / \mathrm{mL}$ CHL or $10 \mu \mathrm{M}$ cytochalasin D pretreatment. (B) Representative confocal microscopy stained with $\mathrm{Zn}^{2+}$ fluorescent probe (Newport Green DCF). The primary intestinal epithelial cells from P. fulvidraco were incubated for $12 \mathrm{~h}$ in control or 40 $\mu \mathrm{M}$ nano-Zn containing medium with or without $2 \mathrm{~h}$ of $10 \mu \mathrm{g} / \mathrm{mL}$ CHL and $10 \mu \mathrm{M}$ cytochalasin D pretreatment. (C) The presence of DCF-stained $\mathrm{Zn}^{2+}$ was demonstrated by flow cytometric analysis of green (FL1) fluorescence intensity. The primary intestinal epithelial cells from P. fulvidraco were incubated for $12 \mathrm{~h}$ in control or $40 \mu \mathrm{M}$ nano-Zn containing medium with or without $2 \mathrm{~h}$ of $10 \mu \mathrm{g} / \mathrm{mL}$ $\mathrm{CHL}$ and $10 \mu \mathrm{M}$ cytochalasin D pretreatment. Values indicate means \pm SEMs, $n=3-6$. Asterisks (*) indicate significant differences between the two groups $(p<0.05, n=3)$. CHL, chlorpromazine; Cyto $\mathrm{D}$, cytochalasin D.

2.4. Higher TG Accumulation in Nano-Zn Group Than in $\mathrm{Znso}_{4}$ Group was Attributable to the Nano-Zn-Induced Activation of PPAR $\gamma$

Compared to the $\mathrm{ZnSO}_{4}$ group, nano- $\mathrm{Zn}$ incubation increased the contents of TG and free fatty acids (FFA), the activities of 6PGD, G6PD, ME, and FAS, up-regulated the mRNA levels of $6 \mathrm{pgd}$, 
g6pd, fas, ppar $\gamma$, fatp4, ifabp, and dgat1, and increased the protein expression of fatty acid transport protein (FATP4) and PPAR $\gamma$ (Figure 4A-F). T0070907, a specific inhibitor of PPAR $\gamma$, alleviated the nano-Zn-induced increase in PPAR $\gamma$ protein expression, and the contents of TG and free fatty acids (FFA), indicating that PPAR $\gamma$ mediated the nano-Zn-induced increase in TG.

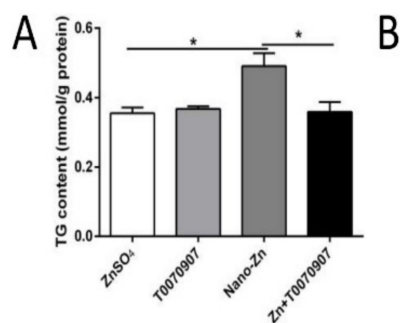

\section{D}

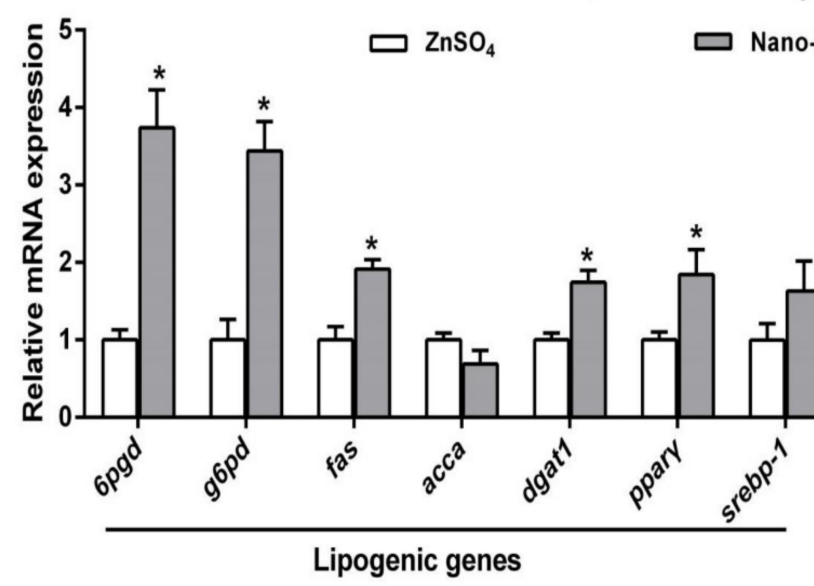

E
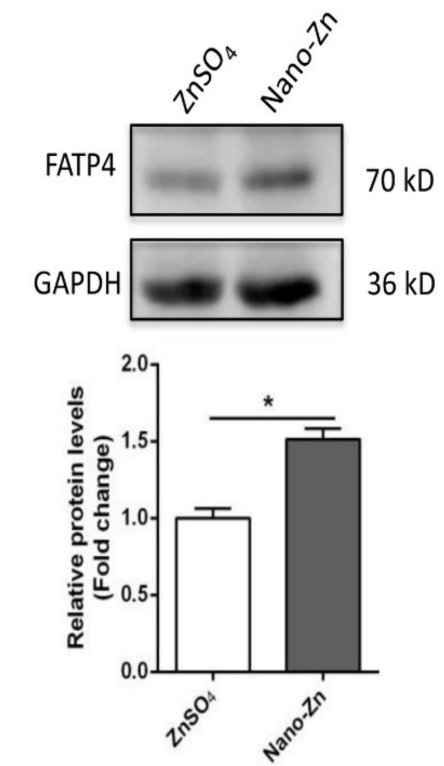
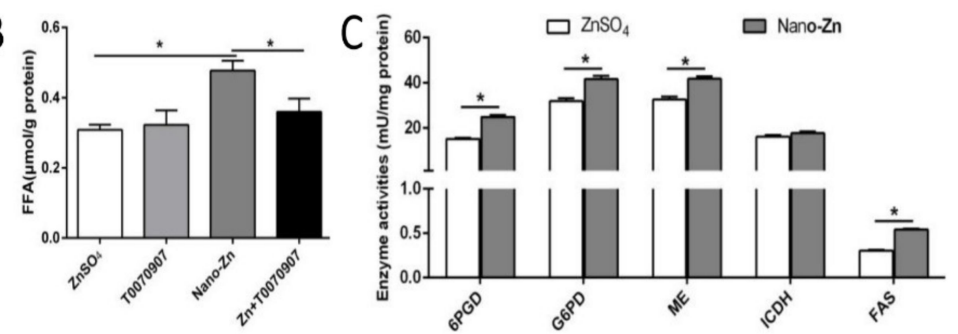

Nano-Zn
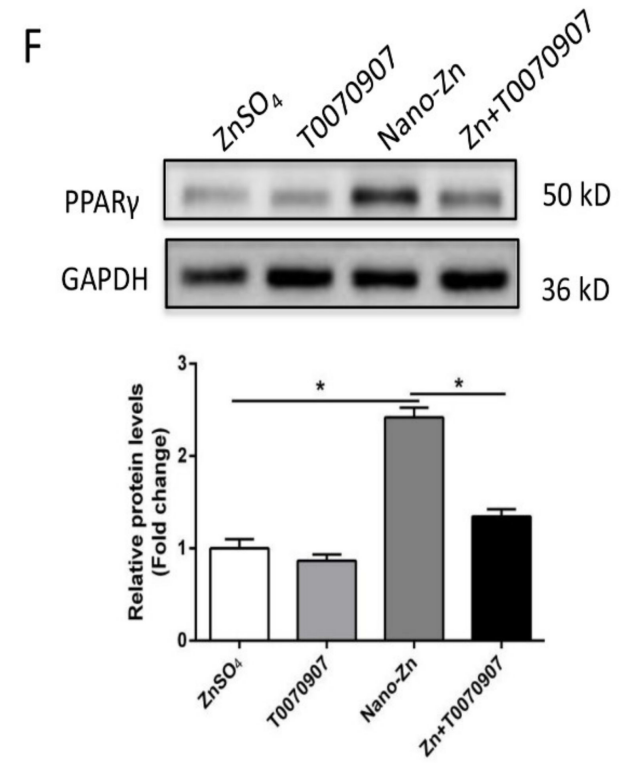

Figure 4. Nano-Zn induced TG accumulation by peroxisome proliferator-activated receptor gamma (PPAR $\gamma$ ) pathway in intestinal epithelial cells. (A) TG content after $24 \mathrm{~h}$ treatments. (B) Free fatty acid content after $24 \mathrm{~h}$ treatments. (C) Enzyme activities. (D) The mRNA levels of lipogenic enzymes after $\mathrm{ZnSO}_{4}$ or nano-Zn incubation for $24 \mathrm{~h}$. (E) Protein levels of fatty acid transport protein 4 (FATP4) after $24 \mathrm{~h}$ of $40 \mu \mathrm{M}$ nano-Zn incubation. (F) Protein levels of PPAR $\gamma$ of intestinal epithelial cells incubated for $24 \mathrm{~h}$ in control or $40 \mu \mathrm{M}$ nano-Zn containing medium with or without $2 \mu \mathrm{M}$ T0070907 pretreatment for $2 \mathrm{~h}$. Values indicate means $\pm \mathrm{SEMs}, n=3-6$. Asterisks $(*)$ indicate significant differences between two groups $(p<0.05, n=3)$. 
Next, we use CHL to inhibit the uptake of nano-Zn via the clathrin pathway to determine the effect of nano-zinc on lipid metabolism. Compared to the $\mathrm{ZnSO}_{4}$ group, nano- $\mathrm{Zn}$ incubation up-regulated the protein expression of MTF- 1 and intracellular free $\mathrm{Zn}^{2+}$ content (Figure 5A-C). CHL pretreatment alleviated the nano- $\mathrm{Zn}$-induced increase in $\mathrm{Zn}^{2+}$ content and alleviated the nano- $\mathrm{Zn}$-induced increase in the PPAR $\gamma$ protein levels and TG and FFA contents (Figure 5C-F).

A
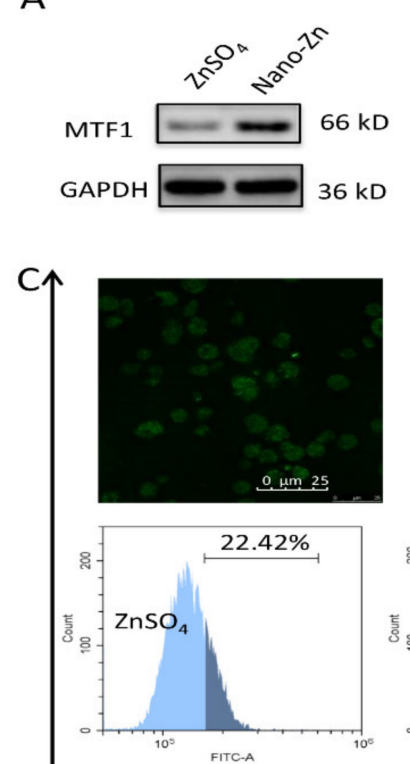

$\mathrm{D}$
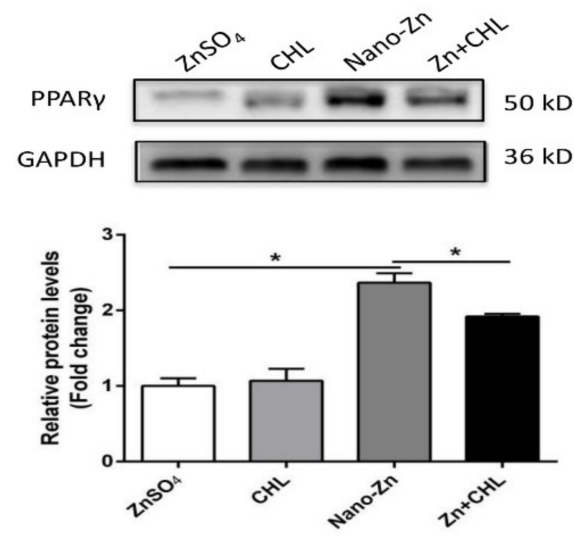
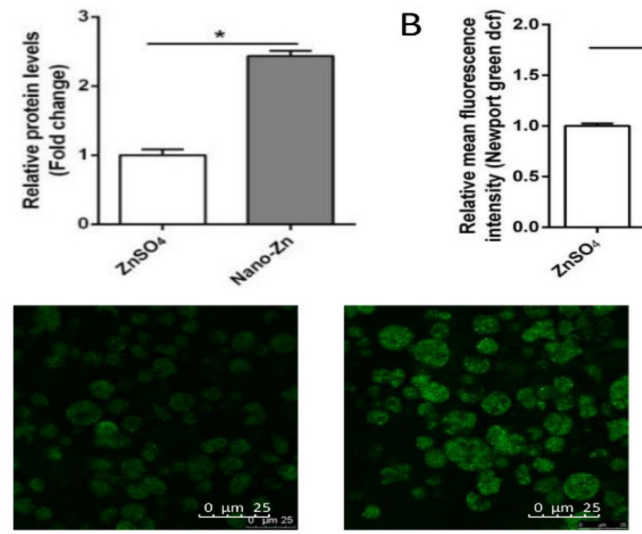

B
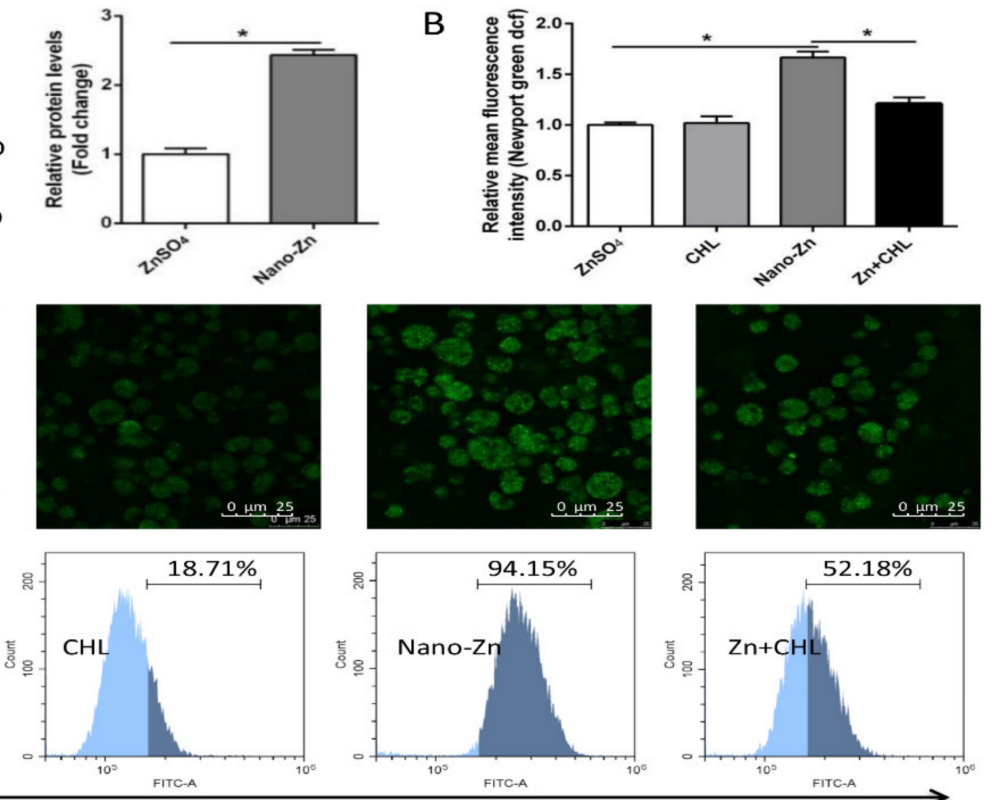

E

$\mathrm{F}$
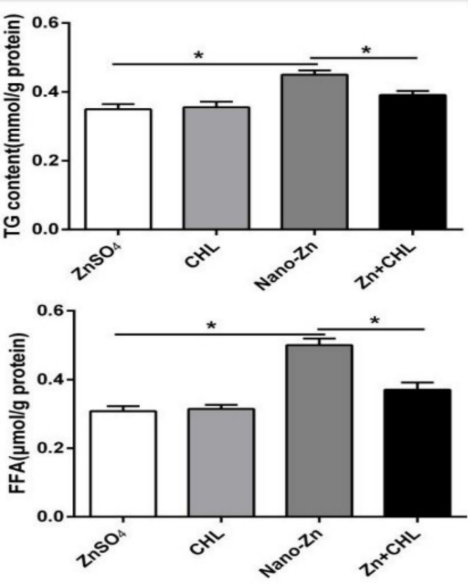

Figure 5. Nano-Zn-induced up-regulation of PPAR $\gamma$ protein levels and TG content is related to nano- $\mathrm{Zn}$ absorption. (A) Protein levels of MTF1 after $40 \mu \mathrm{M}$ nano-Zn incubation for $24 \mathrm{~h}$. (B) Free $\mathrm{Zn}^{2+}$ was quantified by calculating the FL1 (green) mean fluorescence intensity of intestinal epithelial cells incubated for $24 \mathrm{~h}$ in $40 \mu \mathrm{M}$ nano-Zn with $10 \mu \mathrm{g} / \mathrm{mL}$ CHL pretreatment for $2 \mathrm{~h}$. (C) Representative confocal microscopy stained with $\mathrm{Zn}^{2+}$ fluorescent probe (Newport Green DCF), and the presence of DCF-stained $\mathrm{Zn}^{2+}$ was demonstrated by flow cytometric analysis of green (FL1) fluorescence intensity. The primary intestinal epithelial cells from P. fulvidraco were incubated for $24 \mathrm{~h}$ in $\mathrm{ZnSO}_{4}$ or $40 \mu \mathrm{M}$ nano-Zn containing medium with or without $10 \mu \mathrm{g} / \mathrm{mL}$ CHL pretreatment for $2 \mathrm{~h}$. (D) Protein levels of PPAR $\gamma$ of intestinal epithelial cells incubated for $24 \mathrm{~h}$ in control or $40 \mu \mathrm{M}$ nano-Zn containing medium with or without $10 \mu \mathrm{g} / \mathrm{mL}$ CHL pretreatment for $2 \mathrm{~h}$. (E) TG content after $24 \mathrm{~h}$ treatments. (F) Free fatty acid content after $24 \mathrm{~h}$ treatments. Values indicate means \pm SEMs, $n=3-6$. Asterisks (*) indicate significant differences between two groups ( $p<0.05, n=3)$. CHL, chlorpromazine.

To further confirm that nano-Zn-induced changes in TG and FFA were attributable to the change in intracellular free $\mathrm{Zn}^{2+}$ levels, we used $\mathrm{N}, \mathrm{N}, \mathrm{N}^{\prime}, \mathrm{N}^{\prime}$-tetrakis (2-pyridylmethyl) ethylenediamine (TPEN) 
to inhibit Zn uptake. TPEN pretreatment alleviated the nano-Zn-induced increase in intracellular free $\mathrm{Zn}^{2+}$ (Figure 6A-C), PPAR $\gamma$ protein expression, and the contents of TG and FFA (Figure 6D-F). These observations further indicated that the higher TG accumulation in the nano-Zn group than in the $\mathrm{ZnSO}_{4}$ group was attributable to the nano- $\mathrm{Zn}$-induced activation of PPAR $\gamma$.
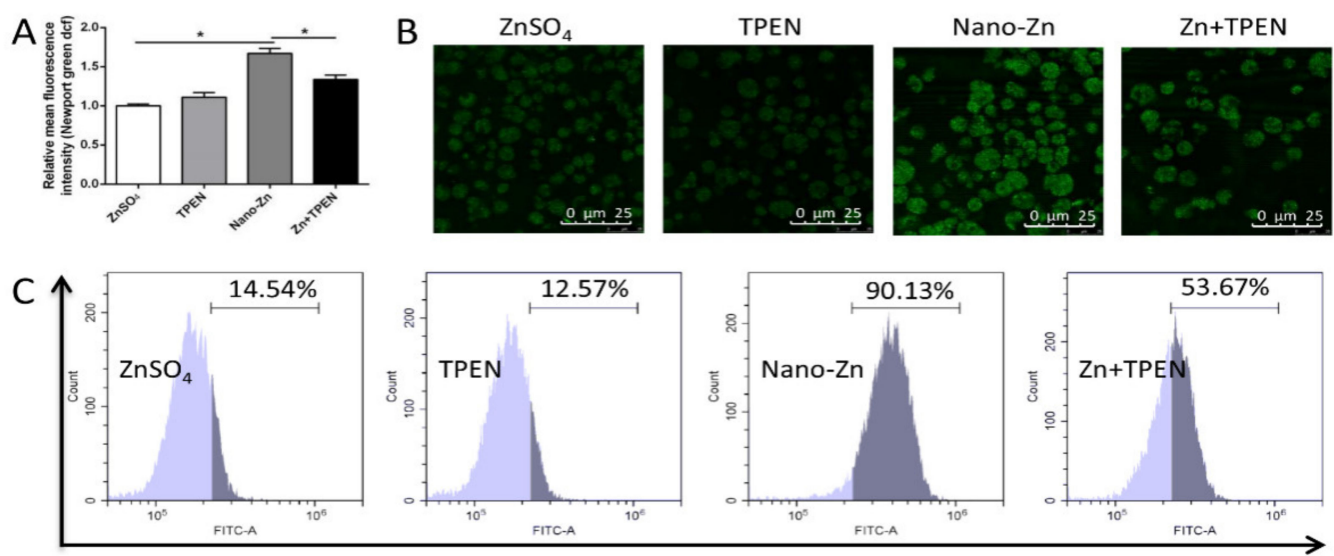

D
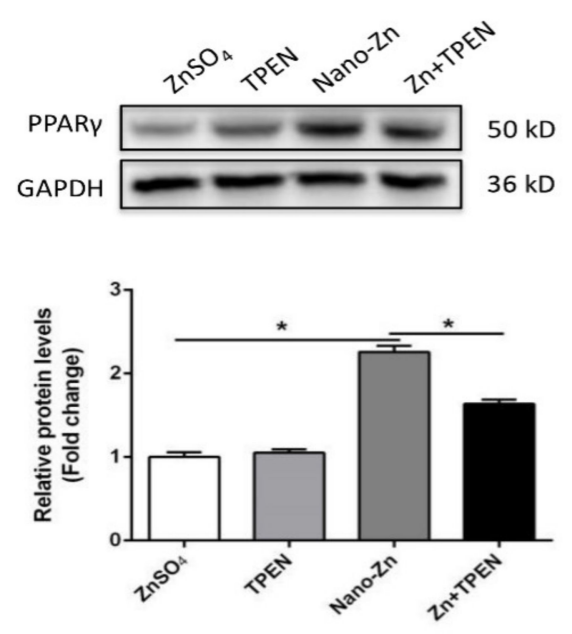

E

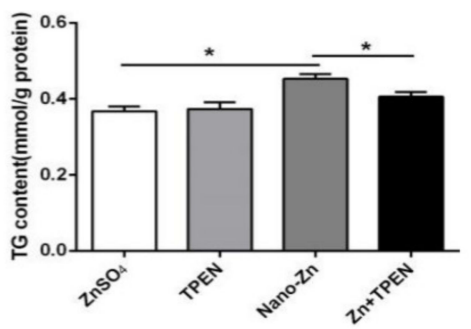

$\mathrm{F}$

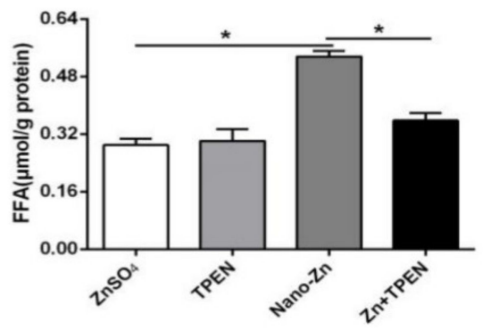

Figure 6. Nano-Zn-induced up-regulation of PPAR $\gamma$ protein levels and TG content is dependent on the release of free $\mathrm{Zn}^{2+}$. (A) Free $\mathrm{Zn}^{2+}$ was quantified by calculating the FL1 (green) mean fluorescence intensity of intestinal epithelial cells incubated for $24 \mathrm{~h}$ in $40 \mu \mathrm{M}$ nano-Zn after $5 \mu \mathrm{M}$ TPEN pretreatment. (B) Representative confocal microscopy stained with $\mathrm{Zn}^{2+}$ fluorescent probe (Newport Green DCF). The primary intestinal epithelial cells from $P$. fulvidraco were incubated for $24 \mathrm{~h}$ in $\mathrm{ZnSO}_{4}$ or $40 \mu \mathrm{M}$ nano-Zn containing medium with or without $5 \mu \mathrm{M}$ TPEN pretreatment for $2 \mathrm{~h}$. (C) The presence of DCF-stained $\mathrm{Zn}^{2+}$ was demonstrated by flow cytometric analysis of green (FL1) fluorescence intensity. The primary intestinal epithelial cells from $P$. fulvidraco were incubated for $24 \mathrm{~h}$ in $\mathrm{ZnSO}_{4}$ or $40 \mu \mathrm{M}$ nano-Zn containing medium with or without $5 \mu \mathrm{M}$ TPEN pretreatment for $2 \mathrm{~h}$. (D) PPAR $\gamma$ protein levels of intestinal epithelial cells incubated for $24 \mathrm{~h}$ in control or $40 \mu \mathrm{M}$ nano- $\mathrm{Zn}$ containing medium with or without $5 \mu \mathrm{M}$ TPEN pretreatment for $2 \mathrm{~h}$. (E) TG content after $24 \mathrm{~h}$ treatment. (F) Free fatty acid content after $24 \mathrm{~h}$ treatments. Values indicate means \pm SEMs, $n=3-6$. Asterisks $(*)$ indicate significant differences between two groups $(p<0.05, n=3)$.

\section{Discussion}

In the present study, we found that, compared to the $\mathrm{ZnSO}_{4}$ group, dietary nano- $\mathrm{Zn}$ promoted growth, increased the $\mathrm{Zn}$ and TG content, and up-regulated lipogenesis in the intestine. Then, our in vitro study further found that the absorption of nano-Zn into intestinal epithelial cells via the 
chathrin-dependent pathway is an energy-consuming process, and $\mathrm{Zn}^{2+}$ increased the NEFA and TG contents via the PPAR $\gamma$ pathway.

In the present study, WG and SGR were higher and FCR was lower in the nano-Zn groups than in the $\mathrm{ZnSO}_{4}$ group, indicating that the appropriate concentrations of nano- $\mathrm{Zn}$ are better than those of $\mathrm{ZnSO}_{4}$ for improving the efficiency of feed utilization and growth performance. Similarly, several studies indicated that $\mathrm{Zn}$ nanoparticles improved the production performance than inorganic $\mathrm{Zn}[16,17]$.

Sufficient $\mathrm{Zn}$ uptake was important for the normal metabolism of fish. The present study indicated that intestinal $\mathrm{Zn}$ content and $m t f-1$ mRNA expression were higher in the nano- $\mathrm{Zn}$ group than in the $\mathrm{ZnSO}_{4}$ group. The different $\mathrm{Zn}$ contents between the two treatments were probably related to the different absorption process and metabolic pathways. Studies suggested that nano- $Z n$ was more bio-available than inorganic $\mathrm{Zn}$, and accordingly resulted in a higher body $\mathrm{Zn}$ concentration [18]. The in vitro study found that the protein level of MTF1 and the mRNA levels of $Z n$ transport genes $(z n t 5, z n t 7, m t$, and $m t f 1)$ were higher in the nano-Zn group than in the $\mathrm{ZnSO}_{4}$ group. These data indicated that these key genes and proteins mediated the $\mathrm{Zn}$ uptake, transport, and metabolism, in agreement with other studies $[6,19]$. Studies suggested that nano-Zn can be dissolved in the digestive tract and accordingly release $\mathrm{Zn}^{2+}$ [20]. Using artificial digestive liquids (i.e., gastric juice, duodenal juice, and bile), Wang et al. [20] observed initial rapid dissolution (ca. $50 \%$ ) of nano-ZnOs in both types (acid and alkaline digestion) of digestion liquids within $10 \mathrm{~min}$. Continuous dissolution of nano-ZnOs proceeded in the acid digestion liquid and most (ca. 85\%) of the added nano-ZnOs dissolved at $120 \mathrm{~min}$. However, no significant dissolution of nano-ZnOs was observed in alkaline digestion after $10 \mathrm{~min}$ [20]. The chemical softness hierarchy may be used in selecting from bi-local, local, and global reactive structures [21], while its inverse chemical hardness hierarchy provides the stability measure [22]. Moreover, Wang et al. [20] speculated that the continuous dissolution of nano-ZnOs in the intestinal lumen would offer highly bioavailable $\mathrm{Zn}^{2+}$. Cytoplasmic $\mathrm{Zn}^{2+}$ is gauged by the transcription factor MTF-1, which induces transcription of $\mathrm{Zn}^{2+}$ chelators such as MTs [4,23], as observed in the present study. Shen et al. [24] pointed out that the MT1 mRNA expression was up-regulated at high Zn concentrations to enhance Zn efflux and, thus, help maintain Zn homeostasis. ZnT5 and ZnT7 localize at the apical membrane of enterocytes, and contribute to the homeostatic maintenance of the secretory pathway functions by supplying $\mathrm{Zn}$ into the lumen $[3,6,25]$.

On the other hand, understanding the endocytosis mechanism of nanoparticles is important to help elucidate the mechanism of nano- $\mathrm{Zn}$ absorption [26]. The present study indicated that $\mathrm{NaN}_{3}$ pretreatment significantly alleviated the uptake of nano-Zn, but nystatin showed no significant effects on the absorption of nano-Zn. $\mathrm{NaN}_{3}$ inhibits energy-dependent endocytosis pathways and effectively inhibits the internalization of nanoparticles [26]. This is indicative of the active uptake of the nanoparticles via an energy-dependent process. Similarly, CHL pretreatment, but not cytochalasin D, significantly alleviated the Zn-induced increase in nano-Zn absorption. CHL can prevent clathrin-mediated endocytosis by disrupting the assembly of the clathrin adaptor protein at the cell surface [27]. These observations clearly suggest that clathrin-mediated endocytosis is the principal mechanism for the cellular internalization of nano- $\mathrm{Zn}$ in the intestinal epithelial cells, in agreement with other studies $[10,14]$.

Although many studies have found that dietary $\mathrm{Zn}$ addition influenced lipid deposition and metabolism [28,29], inorganic Zn has been used in these studies. Different chemical forms of $\mathrm{Zn}$ and other minerals will influence the effects. To our best knowledge, this is the first study to explore the effects and mechanism of dietary nano- $\mathrm{Zn}$ addition influencing lipid deposition and metabolism in fish. Compared to the $\mathrm{ZnSO}_{4}$ group, nano- $\mathrm{Zn}$ increased the TG content, enzymatic activities of ME and FAS, and up-regulated mRNA levels of $6 p g d$, fas, acca, dgat1, ppary, and fatp4. Our in vitro studies also indicated that, compared to the $\mathrm{ZnSO}_{4}$ group, nano- $\mathrm{Zn}$ incubation increased the contents of TG and FFA, activities of 6PGD, G6PD, ME and FAS, up-regulated mRNA levels of $6 p g d, g 6 p d$, fas, ppar $\gamma$, fatp4, ifabp and dgat1, and increased the protein expression of FATP4 and PPAR $\gamma$. 6PGD, G6PD, 
ME, FAS, ACCa, DGAT1, and PPAR $\gamma$ are key enzymes involved in the biosynthesis of fatty acid and TG $[9,29]$. Thus, our study indicated that the higher intestine TG content in the nano-Zn group was due to the up-regulated lipogenesis. Similarly, our other studies indicated that inorganic Zn induced lipolytic responses [29,30]. Moreover, the present study found that T0070907, a specific inhibitor of PPAR $\gamma$, alleviated the nano-Zn-induced increase in PPAR $\gamma$ protein expression and the contents of TG and FFA, indicating that PPAR $\gamma$ mediated the nano-Zn-induced increase in TG. PPAR $\gamma$ is critical for the regulation of lipogenesis and promotes lipid storage [31]. Many studies pointed out that T0070907 reduced PPAR $\gamma$ expression at the protein and transcriptional levels, which is in agreement with many other studies [32-34]. PPAR $\gamma$ is a key transcriptional factor that regulates lipogenesis, and its reduction in expression levels will, in turn, reduce TG accumulation, as shown in another study [35]. Similarly, Zheng et al. [36] reported a positive correlation between mRNA expression of PPAR $\gamma$ and genes encoding lipogenic enzymes (G6PD, 6PGD, and FAS) in yellow catfish. Here, CHL and TPEN pretreatments, which inhibit nano-Zn uptake, alleviated the nano-Zn-induced increase in the PPAR $\gamma$ protein levels and TG and FFA contents, further indicating that nano-Zn-induced changes in TG and FFA were influenced by $\mathrm{Zn}$. Meanwhile, higher TG accumulation in the nano-Zn group than in the $\mathrm{ZnSO}_{4}$ group was attributable to the nano-Zn-induced activation of PPAR $\gamma$ in intestinal epithelial cells.

Here, we characterized the pathway of absorption of nano- $Z n$ into the intestine and elucidated its mechanism of nano- $\mathrm{Zn}$ influencing intestinal lipid metabolism. Nano-Zn was absorbed into the intestine via the endocytosis-mediated clathrin pathway. Compared to $\mathrm{ZnSO}_{4}$, nano- $\mathrm{Zn}$ increased the TG content and up-regulated lipogenesis by activating the PPAR $\gamma$ pathway, which underlies the mechanism of action of nano-Zn for lipid metabolism. Considering that two $\mathrm{Zn}$ sources (inorganic and nano-Zn) widely exist in aquatic environments and aquatic feedstuffs, our study provided important references and mechanistic insights for the evaluation and assessment of $\mathrm{Zn}$ nutrition and hazards in vertebrates.

\section{Materials and Methods}

Two experiments were performed. The experiment performed on animals and cells followed the ethical guidelines of Huazhong Agricultural University (HZAU) for the care and use of laboratory animals and was approved by the Ethical Committee of HZAU (identification code: Fish-2016-0404, Date: 4 April 2016).

\subsection{Expt. 1: In Vivo Study}

The experimental protocols for yellow catfish culture and management were similar to those described in our recent study [29]. Briefly, two experimental diets were formulated to use $\mathrm{ZnSO}_{4}$ ( $\geq 99.0 \%$ in purity, Sinopharm Chemical Reagent Co. Ltd, Shanghai, China) and Zn nanoparticles (nano-Zn) (average size: $40-60 \mathrm{~nm}, \geq 99 \%$ in purity; Sigma) as Zn sources (Supplementary Table S1). Final $\mathrm{Zn}$ contents in the experimental diets were determined to be 23.46 and $23.01 \mathrm{mg} / \mathrm{kg}$ for the $\mathrm{ZnSO}_{4} \bullet 7 \mathrm{H}_{2} \mathrm{O}$ and nano-Zn groups, respectively. At the initiation of the feeding study, 30 uniform-sized fish (mean initial weight: $4.08 \pm 0.09 \mathrm{~g}$ ) were randomly stocked in each fiberglass tank. Each diet was assigned to three tanks in a completely randomized design, with 6 tanks for the experiment. The following values of the parameters of water quality were used: Water temperature from $27.6{ }^{\circ} \mathrm{C}$ to $29.9^{\circ} \mathrm{C} ; \mathrm{pH} 8.3 \pm 0.05$; dissolved oxygen $5.79 \pm 0.08 \mathrm{mg} / \mathrm{L} ; \mathrm{NH}_{4}-\mathrm{N} 0.11 \pm 0.01 \mathrm{mg} / \mathrm{L}$. The experiment continued for 10 weeks.

At the end of the 10 week period, $24 \mathrm{~h}$ after the last feeding, all fish were euthanized (MS-222 at $100 \mathrm{mg} / \mathrm{L}$ ), counted, and weighed to determine survival, WG, and SGR. Then, fish were dissected and the contents of the intestine were gently scraped off. The whole intestine tract was used for the following analysis. A total of four fish per tank were randomly collected and dissected on ice to obtain the intestine samples for TG analysis. For enzyme activity and mRNA expression assays, the intestine samples of twelve fish from each tank (six fish for enzymatic activities and six fish for mRNA expression) were removed immediately using sterile forceps, frozen in liquid $\mathrm{N}_{2}$, and stored at 
$-80{ }^{\circ} \mathrm{C}$ (not longer than 2 weeks) for further processing. Remaining samples were stored at $-80^{\circ} \mathrm{C}$ for determining the $\mathrm{Zn}$ content.

\subsection{Expt. 2: In Vitro Study}

Intestinal epithelial cells were isolated from yellow catfish based on the methods of our previous studies $[4,37]$. Nano-Zn was dissolved in ultra-pure water at $10 \mathrm{mM}$ stock concentrations and then sterilized. The nano-Zn solution was treated with an ultrasonic cleaner for $20 \mathrm{~min}$ before each use. The primary intestinal epithelial cells from $P$. fulvidraco were incubated for $12 \mathrm{~h}$ in $40 \mu \mathrm{M} \mathrm{ZnSO}_{4}$ or $40 \mu \mathrm{M}$ nano-Zn containing medium with or without $2 \mathrm{~h}$ of pretreatment inhibitors. The inhibitors included sodium azide $\left(\mathrm{NaN}_{3}, 10 \mathrm{mM}\right)$ for inhibiting energy-dependent internalization pathways, chlorpromazine (CHL, $10 \mu \mathrm{g} / \mathrm{mL})$, nystatin $(5 \mu \mathrm{g} / \mathrm{mL})$, and cytochalasin-D $(5 \mu \mathrm{g} / \mathrm{mL})$ for inhibiting clathrin-dependent, caveolae-dependent, and phagocytosis-dependent pathways, respectively [14,38]. The concentrations of inhibitors were selected according to our pilot trials and to other in vitro studies [38,39]. They did not adversely influence cell viability. The protein level of MTF1 and the fluorescence intensity of $\mathrm{Zn}$ determined by flow cytometry were determined. Each treatment was performed in triplicate.

To determine the mechanism of nano-Zn influencing lipogenesis, chlorpromazine $(10 \mu \mathrm{g} / \mathrm{mL})$, TPEN $\left(\mathrm{Zn}^{2+}\right.$ chelator, Sigma, MO, USA), and T0070907 (PPAR $\gamma$ inhibitor, Selleck, TX, USA) were used. The concentrations of inhibitors were selected according to our previous studies $[4,37]$. The primary intestinal epithelial cells from P. fulvidraco were incubated for $24 \mathrm{~h}$ in control or $40 \mu \mathrm{M}$ nano-Zn containing medium with or without $2 \mathrm{~h}$ of pretreatment inhibitors. The protein levels of MTF1, PPAR $\gamma$, FATP4, and TGn, FFA content, lipid metabolism enzyme activities, gene expressions, and fluorescence intensity of $\mathrm{Zn}$ by flow cytometry were determined. Each treatment was also performed in triplicate.

\subsection{Cell Viability, TG Content, and Enzymatic Activity Assays}

The MTT assay was performed to test the cell viability according to our recent protocols [37]. TG content was analyzed by using the glycerol 3-phosphate oxidase p-aminophenol method. The enzyme activities of 6PGD, G6PD, ME, ICDH, and FAS followed the methods described by Wei et al. [29]. One unit of enzyme activity (U), defined as the amount of enzyme that converted $1 \mu \mathrm{mol}$ of substrate to product per min at $30^{\circ} \mathrm{C}$, was expressed as units per milligram $(\mathrm{mg})$ of soluble proteins. Soluble protein content was analyzed based on the protocols by Bradford [40]. These analyses were undertaken in triplicates.

\subsection{Real-Time Quantitative PCR ( $q P C R$ )}

The analysis of gene transcription levels was based on our recent publication [36,37]. The primers are given in Supplemental Table S2. A set of ten housekeeping genes (18s rrna, $\beta$-actin, hprt, b2ma, ubce $t u b a, g a p d h, r p l 7, t b p$, and elfa) were selected in order to test their transcription stability. The relative expression of genes was calculated using the $2^{-\Delta \Delta C t}$ method when normalizing to the geometric mean of the best combination of two genes, as analyzed by geNorm [41].

\subsection{Immunoblotting Analysis}

The immunoblotting analysis of MTF1, PPAR $\gamma$, and FATP4 protein expression followed the methods described by our recent publication [29]. Cell lysates were prepared with Radio-Immunoprecipitation Assay (RIPA) buffer (Thermo Fisher Scientific, Waltham, MA, US). Twenty-five micrograms of protein was separated on $12 \%$ sodium dodecyl sulfate (SDS)-polyacrylamide gels. After (sodium dodecyl sulfate polyacrylamide gel electrophoresis (SDS-PAGE), the proteins were transferred to a PVDF membrane, and then blocked with $8 \%(w / v)$ dry milk for $2 \mathrm{~h}$. The membrane was incubated with antibodies against PPAR $\gamma$ (16643-1-AP, Proteintech, Rosemont, IL, US), MTF1 (25383-1-AP, Proteintech), and FATP4 (11013-1-AP, Proteintech) overnight at $4{ }^{\circ} \mathrm{C}$. Then, they were processed with goat anti-rabbit IRDye 800CW secondary antibody (926-32211; Li-Cor Biosciences, 
Lincoln, NE, USA). The protein bands were visualized with an Odyssey Infrared Fluorescent Western Blots Imaging System from Li-Cor Bioscience and quantified by Image-Pro Plus 6.0 (Media Cybernetics, Rockville, MD, USA).

\section{6. $\mathrm{Zn}^{2+}$ Measurement}

The tissue $\mathrm{Zn}$ content was determined by ICP-AES based on the methods by Wu et al. [37]. Newport Green DCF (Ex/Em $=505 / 535 \mathrm{~nm})$ was used to measure intracellular $\mathrm{Zn}^{2+}$ concentrations, based on the methods described in Wei et al. [29].

\subsection{Statistical Analysis}

The results were performed as mean \pm SEM. Data were evaluated using one-way ANOVA, and Duncan's multiple range tests were used to compare the significant differences among more than three treatments. For the comparison between two groups, Student's $t$-tests were employed. The analysis was carried out using SPSS 19.0, and a $P$ value of less than 0.05 was considered significant.

Supplementary Materials: Supplementary materials can be found at http://www.mdpi.com/1422-0067/21/5/1615/ s1.

Author Contributions: Z.L. and S.-C.L. designed the experiment. S.-C.L. conducted the experiment with the help of M.-Q.Z., D.-G.Z. and H.-Y.C., S.-C.L. analyzed the data with the help of Z.L. and M.-Q.Z., S.-C.L. drafted the manuscript and Z.L. revised the manuscript. All the authors read and approved the manuscript. All authors have read and agreed to the published version of the manuscript.

Funding: The study is funded by the National Natural Science Foundation of China (NSFC, grant nos. 31872585, 31422056) and National Key R\&D Program of China (grant no. 2018YFD0900400).

Conflicts of Interest: The authors declare no conflict of interest.

$\begin{array}{ll}\text { Abbreviations } \\ \text { 6PGD } & \text { 6-phosphogluconate dehydrogenase } \\ \text { ACC } & \text { acetyl-CoA carboxylase } \\ \text { ANOVA } & \text { one-way analysis of variance } \\ \text { CF } & \text { condition factor } \\ \text { DGAT } & \text { diacylglycerol acyltransferase } \\ \text { FAS } & \text { fatty acid synthase } \\ \text { FATP4 } & \text { fatty acid transport protein 4 } \\ \text { FCR } & \text { feed conversion rate } \\ \text { FFA } & \text { free fatty acid } \\ \text { FI } & \text { feed intake } \\ \text { G6PD } & \text { glucose 6-phosphate dehydrogenase } \\ \text { ICDH } & \text { isocitrate dehydrogenase } \\ \text { I-FABP } & \text { intestine fatty acid binding protein } \\ \text { ISI } & \text { intestinal somatic index } \\ \text { ME } & \text { malic enzyme } \\ \text { MS-222 } & \text { tricaine methanesulfonate } \\ \text { MT } & \text { metallothionein } \\ \text { MTF-1 } & \text { metal response element-binding transcription factor-1 } \\ \text { NaN } & \text { sodium azide } \\ \text { PPAR } & \text { peroxisome proliferator activated receptor } \\ \text { SEM } & \text { standard error of mean } \\ \text { SGR } & \text { specific growth rate } \\ \text { SREBP } & \text { sterol regulatory element-binding protein } \\ \text { TG } & \text { triglyceride } \\ \end{array}$


TPEN N,N, $\mathrm{N}^{\prime}, \mathrm{N}^{\prime}$-tetrakis (2-pyridylmethyl) ethylenediamine

VSI viscerosomatic index

WG weight gain

ZIP ZRT, IRT-like protein

ZnT Zinc transporter

Zn zinc

ZnSO4 zinc sulfate

Nano-Zn zinc nanoparticles

\section{References}

1. Watanabe, T.; Kiron, V.; Satoh, S.; Wilson, R.P.; Wee, K.L. Trace minerals in fish nutrition. Aquaculture 1997, 151, 185-207. [CrossRef]

2. Bury, N.R.; Walker, P.A.; Glover, C.N. Nutritive metal uptake in teleost fish. J. Exp. Biol. 2003, 206, 11-23. [CrossRef] [PubMed]

3. Kambe, T.; Tsuji, T.; Hashimoto, A.; Itsumura, N. The physiological, biochemical, and molecular roles of zinc transporters in zinc homeostasis and metabolism. Physiol. Rev. 2015, 95, 749-784. [CrossRef] [PubMed]

4. Chen, G.H.; Luo, Z.; Wei, C.C.; Li, D.D.; Pan, Y.X. Six indicator genes for zinc (Zn) homeostasis in freshwater teleost yellow catfish Pelteobagrus fulvidraco: molecular characterization, mRNA tissue expression and transcriptional changes to Zn exposure. Biometals 2018, 31, 527-537. [CrossRef] [PubMed]

5. Palmiter, R.D.; Findley, S.D. Cloning and functional characterization of a mammalian zinc transporter that confers resistance to zinc. EMBO J. 1995, 14, 639-649. [CrossRef]

6. Ishihara, K.; Yamazaki, T.; Ishida, Y.; Suzuki, T.; Oda, K.; Nagao, M.; Yamaguchi-Iwai, Y.; Kambe, T. Zinc transport complexes contribute to the homeostasis maintenance of secretory pathway function in vertebrate cells. J. Biol. Chem. 2006, 281, 17743-17750. [CrossRef]

7. Luo, Z.; Tan, X.Y.; Zheng, J.L.; Chen, Q.L.; Liu, C.X. Quantitative dietary zinc requirement of juvenile yellow catfish Pelteobagrus fulvidraco, and effects on hepatic intermediary metabolism and antioxidant responses. Aquac. 2011, 319, 150-155. [CrossRef]

8. Olechnowicz, J.; Tinkov, A.; Skalny, A.; Suliburska, J. Zinc status is associated with inflammation, oxidative stress, lipid and glucose metabolism. J. Physiol. Sci. 2018, 68, 19-31. [CrossRef]

9. Zheng, J.L.; Luo, Z.; Hu, W.; Liu, C.X.; Chen, Q.L.; Zhu, Q.L.; Gong, Y. Different effects of dietary Zn deficiency and excess on lipid metabolism in yellow catfish Pelteobagrus fulvidraco. Aquaculture 2015, 435, 10-17. [CrossRef]

10. Chithrani, B.D.; Chan, W.C.W. Elucidating the mechanism of cellular uptake and removal of protein-coated gold nanoparticles of different sizes and shapes. Nano Lett. 2007, 7, 1542-1550. [CrossRef]

11. Zhao, C.Y.; Tan, S.X.; Xiao, X.Y.; Qiu, X.S.; Pan, J.Q.; Tang, Z.X. Effects of dietary zinc oxide nanoparticles on growth performance and antioxidant status in broilers. Biol. Trace Elem. Res. 2014, 160, 361-367. [CrossRef] [PubMed]

12. Faiz, H.; Zuberi, A.; Nazir, S.; Rauf, M.; Younus, N. Zinc oxide, zinc sulfate and zinc oxide nanoparticles as source of dietary zinc: comparative effects on growth and hematological indices of juvenile grass carp (Ctenopharyngodon idela). Int. J. Agric. Biol. 2015, 17, 568-574. [CrossRef]

13. Award, A.; Zaglool, A.W.; Ahmed, S.A.A.; Khalil, S.R. Transcriptomic profile change, immunological response and disease resistance of Oreochromis niloticus fed with conventional and Nano-Zinc oxide dietary supplements. Fish Shellfish Immunol. 2019, 93, 336-343.

14. Oh, J.M.; Choi, S.J.; Kim, S.T.; Choy, J.H. Cellular uptake mechanism of an inorganic nanovehicle and its drug conjugates: enhanced efficacy due to clathrin-mediated endocytosis. Bioconjugate Chem. 2006, 17, 1411-1417. [CrossRef]

15. Conner, S.D.; Schmid, S.L. Regulated portals of entry into the cell. Nature 2003, 422, 37-44. [CrossRef]

16. Lina, T.; Jianyang, J.; Fenghua, Z.; Huiying, R.; Wenli, L. Effect of nano-zinc oxide on the production and dressing performance of broiler. Chin. Agricult. Sci. Bull. 2009, 25, 1-5, (in Chinese with English abstract).

17. Mishra, A.; Swain, R.K.; Mishra, S.K.; Panda, N.; Sethy, K. Growth performance and serum biochemical parameters as affected by nano zinc supplementation in layer chicks. Ind J. Anim. Nutr. 2014, 31, 384-388. 
18. Horký, P.; Skalickova, S.; Urbankova, L.; Baholet, D.; Kociova, S.; Richtera, L.; Kabourkova, E.; Lacková, Z.; Cernei, N.; Gagic, M.; et al. Zinc phosphate-based nanoparticles as a novel antibacterial agent: in vivo study on rats after dietary exposure. J. Anim. Sci. Biotechnol. 2019, 10, 17. [CrossRef]

19. Chen, G.H.; Hogstrand, C.; Luo, Z.; Zhang, D.G.; Ling, S.C.; Wu, K. Dietary zinc addition influenced zinc and lipid deposition in the fore-and mid-intestine of juvenile yellow catfish Pelteobagrus fulvidraco. Br. J. Nutr. 2017, 118, 570-579. [CrossRef]

20. Wang, J.; Wang, A.; Wang, W.X. Evaluation of nano-ZnOs as a novel Zn source for marine fish: importance of digestive physiology. Nanotoxicology 2017, 11, 1026-1039. [CrossRef]

21. Matito, E.; Putz, M.V. New link between conceptual density functional theory and electron delocalization. J. Phys. Chem. A 2011, 115, 12459-12462. [CrossRef] [PubMed]

22. Putz, M.V.; Chattaraj, P.K. Electrophilicity kernel and its hierarchy through softness in concenptual density functional theory. Int. J. Quant. Chem. 2013, 113, 2163-2171. [CrossRef]

23. Aydemir, T.B.; Blanchard, R.K.; Cousins, R.J. Zinc supplementation of young men alters metallothionein, zinc transporter, and cytokine gene expression in leukocyte populations. Proc. Natl. Acad. Sci. USA 2006, 103, 1699-1704. [CrossRef]

24. Shen, H.; Qin, H.; Guo, J. Cooperation of metallothionein and zinc transporters for regulating zinc homeostasis in human intestinal Caco-2 cells. Nutr. Res. 2008, 28, 406-413. [CrossRef]

25. Kirschke, C.P.; Huang, L. ZnT7, a novel mammalian zinc transporter, accumulates zinc in the Golgi apparatus. J. Biol. Chem. 2003, 278, 4096-4102. [CrossRef] [PubMed]

26. Mann, S.K.; Czuba, E.; Selby, L.I.; Such, G.K.; Johnston, A.P.R. Quantifying nanoparticle internalization using a high throughput internalization assay. Pharm. Res. 2016, 33, 2421-2432. [CrossRef]

27. Yumoto, R.; Nishikawa, H.; Okamoto, M.; Katayama, H.; Nagai, J.; Takano, M. Clathrin-mediated endocytosis of FITC-albumin in alveolar type II epithelial cell line RLE-6TN. Am. J. Physiol. 2006, 290, 946-955. [CrossRef]

28. Ranasinghe, P.; Wathurapatha, W.S.; Ishara, M.H.; Jayawardana, R.; Galappatthy, P.; Katulanda, P.; Constantine, G.R. Effects of zinc supplementation on serum lipids: a systematic review and meta-analysis. Nutr. Metab. (Lond.) 2015, 12, 26. [CrossRef]

29. Wei, C.C.; Luo, Z.; Hogstrand, C.; Xu, Y.H.; Wu, L.X.; Chen, G.H.; Pan, Y.X.; Song, Y.F. Zinc reduces hepatic lipid deposition and activates lipophagy via $\mathrm{Zn}^{2+} / \mathrm{MTF}-1 / \mathrm{PPAR} \alpha$ and $\mathrm{Ca}^{2+} / \mathrm{CaMKK} \beta / \mathrm{AMPK}$ pathways. FASEB J. 2018, 32, 6666-6680. [CrossRef]

30. Song, Y.F.; Hogstrand, C.; Wei, C.C.; Wu, K.; Pan, Y.X.; Luo, Z. Endoplasmic reticulum (ER) stress and cAMP/PKA pathway mediated Zn-induced hepatic lipolysis. Environ. Pollut. 2017, 228, 256-264. [CrossRef]

31. Rosen, E.D.; Sarraf, P.; Troy, A.E.; Bradwin, G.; Moore, K.; Milstone, D.S.; Spiegelman, B.M.; Mortensen, R.M. $\operatorname{PPAR} \gamma$ is required for the differentiation of adipose tissue in vivo and in vitro. Mol. Cell. 1999, 4, 611-617. [CrossRef]

32. Meng, H.W.; You, H.M.; Yang, Y.; Zhang, Y.L.; Meng, X.M.; Ma, T.T.; Huang, C.; Li, J. 4-methylcoumarin-[5,6-g]-hesperetin attenuates inflammatory responses in alcoholic hepatitis through PPAR- $\gamma$ activation. Toxicol. 2019, 421, 9-21. [CrossRef] [PubMed]

33. Park, S.; Kim, D.S.; Kang, S. Vitamin D deficiency impairs glucose-stimulated insulin secretion and increases insulin resistance by reducing PPAR- $\gamma$ expression in nonobese type 2 diabetic rats. J. Nutr. Biochem. 2016, 27, 257-265. [CrossRef] [PubMed]

34. Zhang, Y.; Yang, X.; Bian, F.; Wu, P.; Xing, S.; Xu, G.; Li, W.; Chi, J.; Ouyang, C.; Zheng, T.; et al. TNF-a promotes early atherosclerosis by increasing transcytosis of LDL across endothelial cells: crosstalk between NF-kB and PPAR- $\gamma$. J. Mol. Cell Cardiol. 2014, 72, 85-94. [CrossRef] [PubMed]

35. Tontonoz, P.; Hu, E.; Spiegelman, B.M. Stimulation of adipogenesis in fibroblasts by PPAR[gamma] 2, a lipid-activated transcription factor. Cell 1994, 79, 1147-1156. [CrossRef]

36. Zheng, J.L.; Luo, Z.; Liu, C.X.; Chen, Q.L.; Zhu, Q.L.; Gong, Y. Differential effects of acute and chronic zinc ( $\mathrm{Zn})$ exposure on hepatic lipid deposition and metabolism in yellow catfish Pelteobagrus fulvidraco. Aquat. Toxicol. 2013, 132-133, 173-181. [CrossRef]

37. Wu, K.; Luo, Z.; Hogstrand, C.; Chen, G.H.; Wei, C.C.; Li, D.D. Zn stimulates the phospholipids biosynthesis via the pathways of oxidative and endoplasmic reticulum stress in the intestine of freshwater teleost yellow catfish. Environ. Sci. Technol. 2018, 52, 9206-9214. [CrossRef] 
38. Khurana, R.K.; Kumar, R.; Gaspar, B.L.; Welsby, G.; Welsby, P.; Kesharwani, P.; Katare, O.P.; Singh, K.K.; Singh, B. Clathrin-mediated endocytic uptake of PUFA enriched self-nanoemulsifying lipidic systems (SNELS) of an anticancer drug against triple negative cancer and DMBA induced preclinical tumor model. Materials Sci. Engin. C 2018, 91, 645-658. [CrossRef]

39. Dutta, D.; Donaldson, J.G. Search for inhibitors of endocytosis: Intended specificity and unintended consequences. Cell. Logist. 2012, 2, 203-208. [CrossRef]

40. Bradford, M.M. A rapid and sensitive method for the quantitation of microgram quantities of protein utilizing the principle of protein-dye binding. Anal. Biochem. 1976, 72, 248-254. [CrossRef]

41. Vandesompele, J.; De Preter, K.; Pattyn, F.; Poppe, B.; Van Roy, N.; De Paepe, A.; Speleman, F. Accurate normalization of real-time quantitative RT-PCR data by genometric averaging of multiple internal control genes. Genome Biol. 2002, 3, research0034. [CrossRef] [PubMed]

(C) 2020 by the authors. Licensee MDPI, Basel, Switzerland. This article is an open access article distributed under the terms and conditions of the Creative Commons Attribution (CC BY) license (http://creativecommons.org/licenses/by/4.0/). 